Article

\title{
Usisa, Saliksik, at Tiyaga: The Task of Philosophizing in Ferriols's Translation of the Apology
}

Jesus Deogracias Z. Principe

\begin{abstract}
This essay is a critical exposition on the translation by Roque Ferriols of Plato's Apology. By reading this particular rendering alongside the original text as well as various translations in English, we will see certain nuances that inform us of how Ferriols views and expresses the philosophical task that Socrates is exhorting us towards in this work. We will see how details regarding verb choice and sentence construction become instrumental in presenting a specific vision of the philosophical endeavour: that it may involve an interrogation of truth-claims (usisa), but cannot simply be reduced to that, as it perhaps also involves a certain inquiry (saliksik) that goes further; more importantly, however, is how it is also and perhaps primarily a call to properly care and strive (tiyaga) for what truly matters.
\end{abstract}

Keywords: Ferriols, Apology, philosophy, translation

\section{Preliminary: Questioning Elenchus}

s we begin our study of philosophy, our sense of what philosophy
itself is all about will most probably be vaguely informed by various
ideas coming from a number of different figures within the history
of ideas. And then, as we proceed to specialize on one particular figure, it
becomes tempting to think of philosophy mainly by following our thinker of
choice, and then allowing ourselves only a passing familiarity-if that
much-with other thinkers' ideas. It is from this kind of narrowing of
perspective that one might easily but also somewhat simplistically formulate
that the idea of philosophy in Descartes is a matter of a search for certitude,
or that Hegel's involves the dialectical unfolding of the spirit, or that
Derrida's is a polemic of deconstruction. From within this kind of
summarizing disposition, one might also confidently put forward that

(C) 2019 Jesus Deogracias Z. Principe

https://www.kritike.org/journal/issue 24/principe june2019.pdf

ISSN 1908-7330

(cc) $\mathrm{BY}-\mathrm{NC}-\mathrm{ND}$ 
Socrates uses a method of aporetic dialogue, one commonly referred to as "Socratic elenchus."

And this is not to say that such a claim is simply baseless. After all, one can turn to the so-called "Socratic" or "earlier" dialogues of Plato, and see therein this kind of discussion between Socrates and some interlocutor which does not seem to arrive at any concrete conclusion. ${ }^{1}$ And so we find inconclusive discussions about, for instance, piety in the Euthyphro, and courage in the Laches; more specifically, we find in these discussions a display of how Socrates confounds his interlocutors and reveals how an idea previously maintained by a person might not have been thought through well enough. We can also find Plato scholars who will clarify for us how this elenchus is supposed to be understood, and thus cement in our minds the idea that this is how we should understand "Socratic method." 2

In addition, it seems that we can also turn to the Apologia (or the Trial of Socrates), wherein we not only have some demonstration of this practice, but we have Socrates in his own words, elaborating on that which he has been doing through the course of his life. He explicitly uses the term $\dot{\varepsilon} \lambda \dot{\varepsilon} \gamma \xi \omega-$

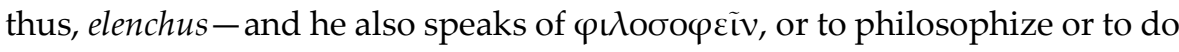
philosophy; and as those Plato scholars are wont to remind us, while the Apologia may or may not be an accurate report of the actual defense trial of the historical Socrates, it most certainly is a portrait in high praise of the thinker, as well as an elegant exhortation to philosophize. ${ }^{3}$ Or as another commentator puts it, the Apologia is "the literary and philosophical demonstration and justification of a certain kind of life." 4

It has become so commonplace for us to think of the Apologia as a defense of the philosophical life that it can keep us from asking the very pertinent question: what exactly do we mean by "philosophy"? What does it mean to philosophize, and what is the philosophical life that we are being encouraged to pursue? Is that question answered by suddenly looking

${ }^{1}$ We will be dealing solely here with Socrates as a character of Plato, and not concern ourselves with the question of the link between this character and the historical Socrates. Readers interested in the debates on this topic are advised to turn to the essays found in: W. J. Prior, ed., Socrates: Critical Assessments - Vol. I: The Socratic Problem and Socratic Ignorance (London: Routledge, 1996).

2 Robinson, for instance, defines for us: "'Elenchus' in the wider sense means examining a person with regard to a statement he has made, by putting to him questions calling for further statements, in the hope that they will determine the meaning and the truth-value of his first statement." R. Robinson, "Elenchus," in Socrates: Critical Assessments - Volume 3: Socratic Method, ed. by W. J. Prior (London: Routledge, 1996), 9.

${ }^{3}$ E. de Strycker and S. R. Slings, "Plato's Apology of Socrates," in Plato's Euthyphro, Apology, and Crito: Critical Essays, ed. by R. Kamtekar (Lanham: Rowman and Littlefield, 2005), 78-85.

${ }^{4}$ D. Clay, Platonic Questions: Dialogues with the Silent Philosopher (University Park, Pennsylvania: The Pennsylvania State University Press, 2000), 43.

(c) 2019 Jesus Deogracias Z. Principe https://www.kritike.org/journal/issue 24/principe june2019.pdf ISSN 1908-7330 


\section{THE TASK OF PHILOSOPHIZING}

elsewhere in the history of philosophy, or by scanning the other Platonic dialogues, or maybe even by the expedient of looking to common sense? Or, again, is this answered by simply reiterating that it is a matter of engaging in the Socratic elenchus? But then, what does the text of the Apologia itself actually say about elenchus in the first place?

Let us look at just some of the instances in which a cognate of $\dot{\varepsilon} \lambda \dot{\varepsilon} \gamma \xi \omega$ is present in the Apologia. Early in the text, we immediately find a sentence wherein Socrates laments that it is so difficult to try to defend himself when none of his accusers are around for him to $\dot{\varepsilon} \lambda \dot{\varepsilon} \gamma \xi \alpha$ เ or "to cross-examine," as stated in 18d5. ${ }^{5}$ Nonetheless, he has no choice but to proceed somehow with his $\dot{\varepsilon} \lambda \varepsilon \dot{\gamma} \gamma \chi \varepsilon เ v$ or "cross-examination," even though there is no one to answer him (in 18d7). Later on, Socrates states that he will set about trying to $\dot{\varepsilon} \lambda \dot{\varepsilon} \gamma \xi \omega \nu$ or "challenge" the pronouncement of the oracle concerning his supposed wisdom (in 21c1). A cognate appears again in which Socrates recounts how he obtained the reputation for being wise, because people think that he must be so, since he is able to $\dot{\varepsilon} \xi \varepsilon \lambda \dot{\varepsilon} \gamma \xi \omega$ or "refute" his interlocutors (in 23a5). Later he puts forward a hypothetical scenario describing his meeting a person who claims to care for virtue in the way that he, Socrates, espouses; he says that he will then $\dot{\varepsilon} \lambda \dot{\varepsilon} \gamma \xi \omega$ or "challenge" that person to verify that he truly does care (in 29e5). And finally, as Socrates reproaches those jurors who had voted against him and sentenced him to death, he warns them that their getting rid of him will not free them from eventually having

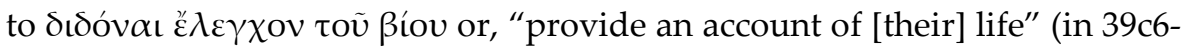
7).

So, elenchus apparently may refer to, in turn, a cross-examination, or a challenge, or a refutation, or providing an account, depending on the context in which the word is used. It might therefore be wise to remind ourselves that we cannot simply trot out the word elenchus and vaunt it as Socrates' method and conclude that what this means is already singularly and sufficiently clear. What is meant by elenchus certainly deserves further scrutiny. ${ }^{6}$ But that is not the question we are asking. Our main question"what is philosophy?", as can be gleaned from the Apologia-will not be answered by simply fixating on the term elenchus and trying to shed further light on that particular word. It might be good for us to be reminded that “Socrates has no special word for his 'method,' nor does he ever refer to what

${ }^{5}$ When summarizing, I will be using my own words; when putting forward a direct English translation of the text, I will be using, within quotation marks, the translation of Rowe (as that is the most recent) unless otherwise specified. All instances of the text being translated into Filipino come from Ferriols. For Rowe's translation, see: Plato, The Last Days of Socrates, trans. by C. Rowe (London, Penguin, 2010). For Ferriols's translation, see: Roque Ferriols, Mga Sinaunang Griyego (Quezon City: Ateneo de Manila University, 1999).

${ }^{6}$ Readers interested in these explorations are advised to turn to the essays found in: W. J. Prior, ed., Socrates: Critical Assessments - Vol. III: Socratic Method (London: Routledge, 1996).

(c) 2019 Jesus Deogracias Z. Principe

https://www.kritike.org/journal/issue 24/principe june2019.pdf

ISSN 1908-7330

(cc) BY-NC-ND 
he does as reflecting a method."7 There are many other terms employed by Socrates in describing to us what he does within the philosophical life, and that also deserves closer scrutiny. A more careful reading of the text should lead us beyond fixating on one particular word-elenchus-and its cognates, and trying to read into that alone a supposed method or understanding of philosophy. So, the broader question may be asked: how will the different ways by which Socrates himself speaks of what he does enlighten us about doing philosophy?

However, paying close attention to what Socrates says of what he does can be tricky. We need to be conscious of-and cautious of $-\mathrm{a}$ hermeneutical conundrum peculiar to someone studying the Platonic Socrates. We are warned that, "[Socrates] is our model of a philosopher. The danger is that even the most scholarly of us will make Socrates her own ideal of philosophy, and so reveal more of herself than of history when she writes of Socrates." 8 Now, this difficulty is perennially present for any scholar thinking of-and perhaps idealizing-his or her philosopher, but this is arguably more pronounced in the Plato scholar trying to understand the character of Socrates, and perhaps, most of all, in the translator who strives to make Socrates' words come alive in a new tongue. It has become axiomatic in hermeneutics to recognize that the translator cannot but place something of himself or herself - the peculiarities of his/her background and personality and mentality -into his/her rendering of the work. Now while this rightly is a word of caution for someone who is just about to translate, we can very well use this idea as a source of insight as we look at a work of translation that has already been done.

In other words, we can augment the question at hand in this essay as not simply being, how does Socrates speak of his philosophical task in the Apologia, but instead, going further, what we will explore here is this: how does Roque Ferriols, in his translating the Apologia from the original Greek into Filipino, understand the philosophical task of Socrates, as can be gleaned from the translation of the text itself?

We will try to shed light on these related questions by consulting the original text of the Apologia as seen in the standard scholarly resource, the Oxford Classical Text, and by looking at Ferriols's translation as can be found in his Mga Sinaunang Griyego; our review of Ferriols's rendering will be done side by side with six contemporary translations of the dialogue into English

${ }^{8}$ P. Woodruff, "Expert Knowledge in the Apology and the Laches: What a General Needs to Know," in Socrates: Critical Assessments - Vol. 1: The Socratic Problem and Socratic Ignorance, 276.
}

7 T. C. Brickhouse and N. D. Smith, Plato's Socrates (New York: Oxford University

(c) 2019 Jesus Deogracias Z. Principe https://www.kritike.org/journal/issue 24/principe june2019.pdf ISSN 1908-7330 


\section{THE TASK OF PHILOSOPHIZING}

(Allen, ${ }^{9}$ Fowler, ${ }^{10}$ Grube, ${ }^{11}$ Rowe,,${ }^{12}$ Tredennick and Tarrant, ${ }^{13}$ and West $^{14}$ ). We will first elaborate on the part of the text in which Socrates recounts how he received both his reputation for wisdom and his mission from the gods (from 21a to 23d); we will then turn to the part of the text in which he speaks specifically of philosophy (from $28 \mathrm{~b}$ to $29 \mathrm{~d}$ ); and finally, we will pay attention to what exactly is that matter about which Socrates is trying to persuade others (from $29 \mathrm{~d}$ to $41 \mathrm{e}$ ). A brief conclusion will summarize and develop our findings.

\section{Part 1: Examining through Examination}

At the start of the text, Socrates says that before he defends himself against the formal charges that have been raised against him, he would need to try to overcome a certain prejudice that most likely has long been held by many people, including the jurors; he is referring to the reputation that he, Socrates, has had for a long time of being wise. The text speaks of "a certain

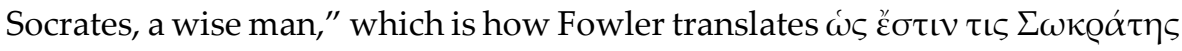

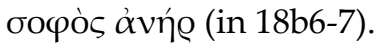

It might be of interest to note how Ferriols translates this line as, “... si Sokrates daw ay isang taong nagmamarunong." While Fowler's and the other translations in English depend on the implicit irony-of seeming to be a wise man versus truly being wise-which is what will open up the discussion on what comprises wisdom, Ferriols, in his rendering, cuts through the ambiguity. While it can be argued that the negative anticipation in Ferriols's translation is not yet provided for in the Greek text, it has the advantage of making clear to the reader not only why he would have been found offensive by others and be in his current predicament, but more significantly, by using "nagmamarunong," he has chosen to anticipate and posit explicitly the problematic failing that he will find, ironically, not in himself, but in those others who then despise him. This early observation, while only tangentially related to the main points we will be developing,

\footnotetext{
${ }^{9}$ For Allen's translation, see Plato, The Dialogues of Plato: Volume 1, trans. by R. E. Allen, (New Haven: Yale University Press, 1984).

${ }^{10}$ For Fowler's translation, see Plato, Plato - Volume 1: Euthyphro, Apology, Crito, Phaedo, Phaedrus, trans. by H. N. Fowler, (Cambridge, Mass.: Harvard University Press, 1914).

${ }^{11}$ For Grube's translation, see Plato, "Apology," trans. by G.M.A. Grube in Plato: Complete Works, ed. by J. Cooper (Indianapolis: Hackett, 1997);

${ }^{12}$ For Rowe's translation, see Plato, The Last Days of Socrates, trans. by C. Rowe (London, Penguin, 2010).

${ }^{13}$ For Tredennick and Tarrant's translation, see Plato, The Last Days of Socrates, trans. by H. Tredennick and H. Tarrant (London, Penguin, 1993).

${ }^{14}$ For West's translation, see Plato, "Apology," trans. by T. G. West, in Four Texts on Socrates, rev. ed., ed. by T. G. and G. S. West (Ithaca: Cornell University Press, 1998).

(c) 2019 Jesus Deogracias Z. Principe

https://www.kritike.org/journal/issue 24/principe june2019.pdf

ISSN 1908-7330

(c) BY-NC-ND
} 
already presents to us a sense of the unique expressiveness of Ferriols's interpretive choices.

But let us proceed to our main concern. Socrates recounts how this prejudice against him started when he had learned of the pronouncement of

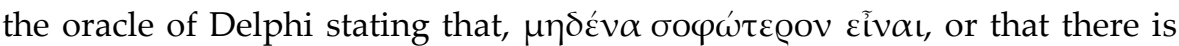
"no one wiser" than Socrates (in 21a6-7). He confesses that his immediate response to this claim was one of perplexity, since he does not think of himself as wise in any way, either large or small. However, as a tenet of faith, he must maintain that the divine oracle could not possible be stating a falsehood. This apparent contradiction obliges Socrates to scrutinize the truth-claim put forward by the oracle.

Let us look at the terms that Socrates employs to express these attempts at assessing the oracle's pronouncement.

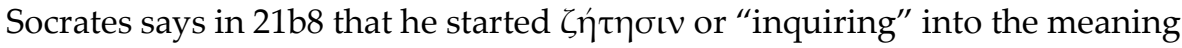
of the oracle's claim. In Ferriols, this is rendered as, "paghahanap ng kahulugan."

Socrates then says in $21 \mathrm{c} 1$ that he made it a point to $\dot{\varepsilon} \lambda \dot{\varepsilon} \gamma \xi \omega \nu$ or "challenge" the oracle's claim. In Ferriols, this elenchon of the oracle's claim is rendered as "mauusisa." This will be done more specifically through the expedient of talking to people who are supposed to be wise, which we will turn to shortly.

But focusing first on his reaction to the oracle's pronouncement, we

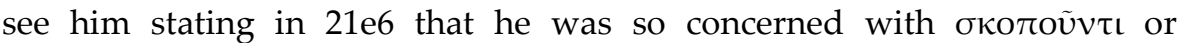
"searching" for its meaning. This is rendered by Ferriols as "nag-uusisa," which echoes what he had just seen in 21c1, in his translating of elenchōn.

We return to another form of $\zeta \eta \tau \omega$ in 22a4 when Socrates tells us that

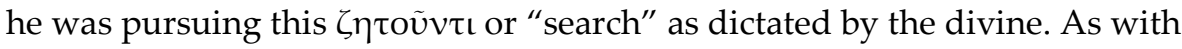
the earlier presence of this Greek verb in 21b8, we find Ferriols consistently translating this as "paghahanap."

Having obtained some indication that perhaps the divinity is right after all, Socrates pursues his inquiry further, this time, not with a view to disproving the oracle's claim, but of confirming, or at least, testing it with further experience. He says that he proceeds with this $\zeta \eta \tau o v v \tau \tau \iota$ to ensure that the claim is, in fact, $\alpha v \varepsilon$ ć $\varepsilon \gamma \kappa \tau$ (in 22a7-8). This latter term is translated by Rowe as "unrefuted," or in other words, one might say that Socrates has gone beyond the attempt to falsify and, turning things around, instead is now trying to establish that what the oracle had claimed is true. ${ }^{15}$ We find this

${ }^{15}$ A more neutral approach to the line-which could then be taken on either a more positive or more negative sense - can be seen in two of the English translations: in Allen, we have the more neutral statement that Socrates's thoroughness in pursuing this was out of a desire, "to not leave the oracle untested;" in Tredennick and Tarrant, we have, "to establish the truth of the

(c) 2019 Jesus Deogracias Z. Principe https://www.kritike.org/journal/issue 24/principe june2019.pdf 


\section{THE TASK OF PHILOSOPHIZING}

sense strongly asserted in the rendering of Ferriols, wherein Socrates is pursuing this search "hangga't luminaw sa akin na napakatibay at di malalansag ang winika ng diyos."

He will say once more that all of this has been a matter of $\dot{\varepsilon} \xi \varepsilon \tau \alpha \dot{q} \sigma \varepsilon \omega \varsigma$ or "inquiry" of the meaning of the oracle's pronouncement (in 22e6). We should note that Ferriols translates this verb to "pag-uusisa," employing, once again, the term that he had used for elenchōn as we had seen in 21c1 and $21 \mathrm{e} 6$.

We have so far found a number of different Greek verbs used by Socrates to refer to the general act of seeking the meaning or assessing the truth claim of the oracle. In several instances of rendering these into Filipino, Ferriols favors the use of the word usisa applied not exclusively to any one Greek verb but to several. We need to consider as we proceed whether usisa thus might be a significant term for Ferriols.

For the moment, let us look at how exactly the examination works. As stated earlier, this assessing of the truth-claim of the oracle's pronouncement-or inquiring about its meaning-would be done through talking to people who are supposed to be wise. Since the pronouncement was that "No one is wiser than Socrates," by talking to persons deemed to be wise, that claim would be put to the test and would be proven falsified should he encounter someone who turns out to be wiser than he is.

He says in 21c3 that he first went to one of the very public personages or politicians (tōn politikōn) in town, a man reputed for his wisdom. His $\delta\llcorner\alpha \sigma \kappa о \pi \tilde{\omega} \nu$ or "examination" of this man revealed that while he might seem to be wise (and perhaps even imagines himself to be so), the plain fact is that he is not. Ferriols uses the verb "inusisa" to refer to this examination.

He goes about trying to test the meaning of the oracle's pronouncement further by talking to more people; and after the politicians, he moves on to the poets (tous poiétas), who he surmises must have some kind of wisdom as the basis of their creative works. Rowe translates $\varepsilon \pi^{\prime}$ $\alpha \dot{\tau} \tau о \varphi \omega \omega \varrho ~ \kappa \alpha \tau \alpha \lambda \eta \psi o ́ \mu \varepsilon v o \varsigma$ (in 22b1-2) with the phrase, "I'd catch myself red-handed," which idiomatically tries to capture the sense of how the act of speaking to the poets about their beautiful writings ought itself to be the very proof of Socrates's own ignorance. Or as Ferriols puts it, "huling huli ko ang aking sarili." Would his conversations with the poets prove Socrates less wise than they? He instead discovers that the poets are sadly betrayed by their ignorance of whatever sense might be found in their own writings, which must be, Socrates concludes, the result of some divine inspiration rather than wisdom.

oracle once for all," leaving ambiguous whether one takes the oracle to be speaking the truth, or one is determining the truth or falsehood of the oracle.

(c) 2019 Jesus Deogracias Z. Principe

https://www.kritike.org/journal/issue 24/principe june2019.pdf

ISSN 1908-7330

(cc) BY-NC-ND 
He finally goes to the artisans (tois cheirotéchnas), with whom he knows he will find many fine things, which he again first surmises must be the fruit of wisdom; but here again, he concludes that these people, too, fall short of wisdom, through the mistake of thinking that they are knowledgeable or wise, even regarding matters about which they actually are not.

He finds that all these types of people collectively share the ultimate foolishness (amathia) of thinking that they know when, in truth, they do not (thus, the aptness of Ferriols use of "nagmamarunong" earlier). This is how he is led to the conclusion that the oracle was speaking rightly after all: Socrates is wisest among men, understanding that his wisdom consisting of his humble recognition of his own ignorance; or to be more precise, Socrates acknowledges that he is of no worth (oudenos axios) with regard to wisdom (pros sophian).

Socrates ends the story by speaking of the present, how all this has led to enmity and to his current predicament, as it seemed to other peopleinterlocutors and onlookers - that he was showing off his wisdom when he engaged in this $\dot{\varepsilon} \xi \varepsilon \lambda \dot{\varepsilon} \gamma \xi \omega$ of others (in 23a5). It is of interest to see how the different translators present varying degrees of force in the antagonism present between Socrates and his interlocutors. ${ }^{16}$ For instance, in Rowe, the interlocutors suppose themselves to have been refuted, whereas Ferriols more mildly describes what Socrates is doing in terms of "habang ako'y nagtatanong, na inuusisa ko ang dunong ng aking kapuwa." Our interest in this is how the choice of tone and the choice of verbs inform us of how the translator views what Socrates is doing: either aggressively refuting and proving wrong in most of the English translations, or, so one could read, more mildly questioning and scrutinizing in Ferriols.

Socrates then adds that some young men follow him as he goes about this endeavour, since they delight in listening as other people are $\dot{\varepsilon} \xi \varepsilon \tau \alpha \zeta o \mu \varepsilon \dot{v} \omega \omega \nu$ (in23c4) or "tested" by Socrates. They then take it upon

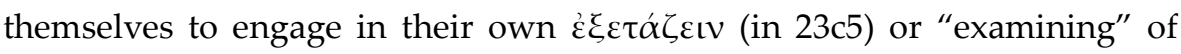
others. In their doing so, those who have been $\dot{\varepsilon} \xi \varepsilon \tau \alpha \zeta o$ $\mu \varepsilon v o l$ (in23c8), that is to say, their "victims," end up hating Socrates, the figure the young men attempt to emulate. We see in this dense paragraph a form of the same verb thrice used. We also see here Rowe (and similarly Tredennick and Tarrant) employing three different English words, perhaps to avoid potentially

${ }^{16}$ For Rowe and for West, Socrates has refuted the interlocutors; Fowler uses the word, "confute;" in putting forward the same idea; for Tredennick and Tarrant, Socrates has disproven his interlocutor's claim to wisdom; and similarly in Grube, Socrates ends up proving himself to have the wisdom that his interlocutor did not have. More neutrally (and more an echo of the Ferriols's translation), we have Allen rendering this line as Socrates being engaged in testing others.

(c) 2019 Jesus Deogracias Z. Principe https://www.kritike.org/journal/issue 24/principe june2019.pdf 


\section{THE TASK OF PHILOSOPHIZING}

tedious repetition in such a compact sentence. By contrast, our other translators-Allen, Fowler and Grube-more faithfully select and repeat one verb to reflect the repetition in the original. We also find this kind of fidelity to the original in Ferriols, who uses the words "pag-uusisa," "mang-usisa," and, "mga inusisa" respectively for these three forms of exetazō mentioned above.

As we move forward in the text, we will find this verb reiterated (in 33c3) when Socrates answers the question on why these young men, who he has supposedly corrupted, enjoy being around him: it has to do with how they find amusing the way Socrates trumps those who are "examined" or $\dot{\varepsilon} \xi \varepsilon \tau \alpha \zeta o \mu \varepsilon \dot{v}$ oı $\varsigma$. This is rendered by Ferriols as "nag-uusisa sa mga nagaakalang marunong."

We need to distinguish how there are actually two examinations at work here: The first examination refers to the testing of the pronouncement of the oracle, as to whether or not it is the case that there is no one wiser than Socrates. This is done by way of the second examination, by engaging people-particularly those with some kind of reputation for wisdom-in conversation, and on that basis, assessing whether or not this person has a greater wisdom compared to Socrates.

Ferriols uses usisa for three different Greek verbs that refer to Socrates's assessing of the pronouncement of the oracle: $\dot{\varepsilon} \lambda \dot{\varepsilon} \gamma \xi \omega \nu$ in 21c1,

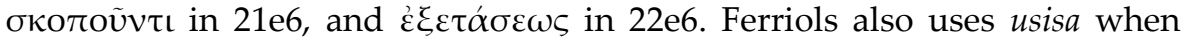
referring to what Socrates does in the course of the conversations: for $\delta\llcorner\alpha \sigma \kappa о \pi \tilde{\omega} \nu$ in $21 \mathrm{c3}$, and $\dot{\varepsilon} \xi \varepsilon \lambda \varepsilon \gamma \xi \xi$ in 23a5, and most significantly, for the

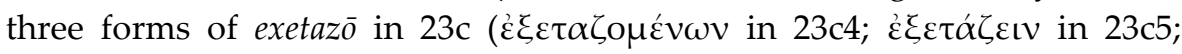

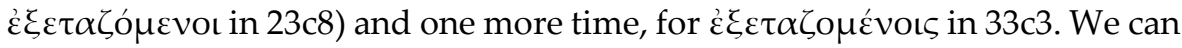
perhaps stipulate on this basis that Ferriols prefers the use of this verb, usisa to refer specifically to an instance of testing of some kind of truth-claim: whether this be the explicit and specific truth claim that had come from the oracle, or the many truth-claims he encountered, which, while unspecified as to their particulars, the presence of which must certainly be inferred from the conversations that he had with many different interlocutors.

As stated above, Socrates informs us that it has been this practice of his which has led to the enmity of others and the source of that reputation he has; however, he also informs us that he still goes about as he had in the past.

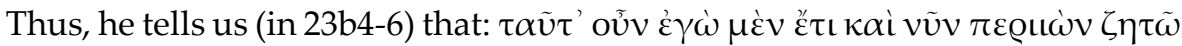

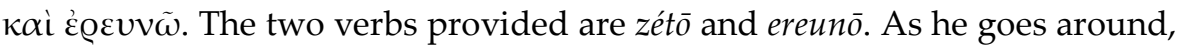
even now, he is, in Fowler's translation, "seeking and searching." In Rowe's translation, the two verbs are collapsed into "search." Ferriols translates these two verbs as, "hinahanap at sinasaliksik."

What is the object of this seeking and searching? The sentence next mentions anyone who seems to Socrates to be wise. Conceivably, one would

(c) 2019 Jesus Deogracias Z. Principe

https://www.kritike.org/journal/issue 24/principe june2019.pdf

ISSN 1908-7330

(c) ) BY-NC-ND 
suppose this to be the direct object of these verbs, that the continued endeavour is a matter of seeking out those with a reputation for wisdom, in order to refute them. We could interpret this-along the lines of Rowe's rendering - such that the two verbs used here refer to one and the same thing, the finding and assessing, and ultimately, refuting of the truth-claim of another person. And yet, Rowe aside, the other translators choose to provide two distinct English verbs, in a way that more closely echoes the original; this seems to allow us to posit that beyond the finding (zétō), there is some form of "inquiry" (Allen) or, "search" (Tredennick and Tarrant) or, "investigation" (Fowler, Grube, West) or, "pananaliksik" (Ferriols) that is taking place. These translators, in their word choice, all acknowledge the difference between the verb used here (ereunō) and all the different verbs used earlier to refer to the assessment of truth-claims. So, when we see Ferriols use a new term heresaliksik-in distinction from the earlier usisa, we are alerted to the possibility of exploring further whether this difference is relevant. The assessment of truth-claims, important as it may be, might not be all there is to what Socrates does. In other words, we can ask: is there something more-beyond the assessment of truth-claims -involved in doing philosophy?

\section{Part 2: The Mission of Philosophy}

Immediately following Socrates's story of the double examination, he presents an audacious parallelism between himself and the Homeric heroes of old. He first posits a statement from a hypothetical juror: wouldn't Socrates wish to rethink everything that he has been doing, since it had landed him in this predicament, in which his life itself is at stake? His reply to his own question is to ask whether a real man cared about life or death, or any possible danger to himself; instead, wouldn't a real man care only about the question of whether or not he was doing the right thing, doing what needed to be done, no matter what? He explicitly compares himself to Achilles, who gladly faced death as long as he would first be able to avenge his friend, Patroclus. He then shifts from this specific heroic figure to the more general heroic figure of a soldier who steadfastly remains wherever he might be stationed by his superior, even in the face of great danger.

He then speaks of his own task in terms of his having been given an order by his superior, the divine, and he presents this order as follows:

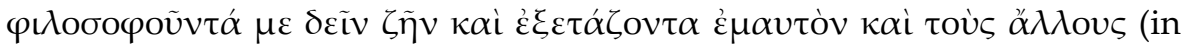
28e5-6). ${ }^{17}$ The first half of this line (the first four words) would give us "to live

${ }^{17}$ The line in 28e5-6 is rendered by the various translators as follows: Ferriols: “... na kailangan kong mabuhay na namimilosopiya, sa pagsasaliksik sa sarili at sa kapuwa;" Allen: "... to live in the pursuit of wisdom, examining myself and others; Fowler: "... to spend my life in philosophy and in examining myself and others;" Grube: "... to live the life of the philosopher,

(c) 2019 Jesus Deogracias Z. Principe https://www.kritike.org/journal/issue 24/principe june2019.pdf ISSN 1908-7330 


\section{THE TASK OF PHILOSOPHIZING}

a life of philosophy," whereas the second half of this line (the last five words) would give us "examining myself and others." We have, here, two verbal phrases with the conjunction, kai between them. This allows for a potential ambiguity present in the Greek and potentially echoed in English, wherein the two verbs involved can either be thought of as two distinct tasks (I was running and jumping), or the latter is implied in the former without the two necessarily being identified (I was running and working up a sweat), and finally it could also refer to an identification, with two verbs being employed for the sake of emphasis (I was running and pounding the streets).

This means that there are different possible ways of construing the link between philosophounta and exetazonta. Is the philosophical life identical with this examination of one's self and others? Or are these two different tasks? Distinct from, and yet reflective of, our question on the verbs usisa and saliksik as we have seen earlier, this statement here begs a new question of what "philosophy" would mean if we are to distinguish it from this examination. Or could we consider the possibility of some kind of examination being implied in philosophy without their being simply identical? That is to say, could philosophy involve some kind of examination, but in such a way that it need not be simply reducible to that?

Let us turn to the various translations.

The translations of Fowler and West maintain the use of the conjunction, translating kai with "and," such that in doing so, they retain the ambiguity inherent in the presence of kai in the text. The translations of Allen, Grube, Rowe, and Tredennick and Tarrant make use of a comma, and while that similarly allows for the same kind of ambiguity, it can also be argued that the punctuation mark allows for a reading that leans more towards the latter verbal phrase being an extension of the first, clarifying what would be involved in the former, or even making an identification between those two terms. This is arguably how we can read the rendering of Ferriols when he gives us: "...na kailangan kong mabuhay sa pilosopiya, sa pagsasaliksik sa sarili at sa kapuwa...." This pananaliksik clarifies what it means to live in philosophy, either by way of identification, or at least as presenting one aspect of it.

We find pananaliksik as Ferriols's way of translating the verb: exetazonta. We also find that all of the English translations use a form of "to examine" for exetazonta. We should also recall that we had already seen on a number of occasions that some form of the term exetazonta had been used to refer to the examination of the pronouncement of the oracle and the examination of the wisdom of Socrates's interlocutors.

to examine myself and others;" Rowe: “... to live a life of philosophy, examining myself and others;" Tredennick andTarrant: "... to the duty of leading the philosophic life, examining myself and others;" West: "... to live philosophizing and examining myself and others."

(c) 2019 Jesus Deogracias Z. Principe

https://www.kritike.org/journal/issue 24/principe june2019.pdf

ISSN 1908-7330

(c) ) BY-NC-ND 
Fowler and West are the only translators who use a form of "examine" for exetazonta in both the discussion of the assessment for truthclaims and this line we are analyzing here. Their renderings would give a reader reason to suppose that philosophizing primarily means this assessment of truth-claims. We have seen how Rowe, and Tredennick and Tarrant did not, in the earlier discussion of exetazonta, use consistently any one particular word, and so their use of "examine," here, does not lend itself to one particular interpretation of the verb choice; since they present us with various terms, we are discouraged from taking any of them in any strict technical sense.

By contrast, Allen had earlier consistently used a form of "test," while for this line he uses "examining." One could simply read these terms as synonymous, and leave it at that; what we mean by "examining" is nothing more than the testing of truth-claims. However, the difference between verbs could also be read as indicative of a recognition that there could be something more at work in philosophizing, something that could be called "examination" that goes beyond any testing of truth-claims. And this might also be a way we can understand Ferriols's choice to translate exetazonta here, not with usisa, as he we have previously seen him do (in 23c and 33c3), but instead with saliksik. One can consider these two Filipino verbs as being simply synonymous, or instead, one might take the philosophical taskexpressed here as a form of saliksik - to extend beyond what one does in usisa. This is consistent with the suggestion that was earlier posited, at the end of the previous section of this essay.

Having asserted what his task is, Socrates then provides a hypothetical scenario; he imagines the possibility of the jury showing him leniency in exchange for his giving up on this task. Speaking on behalf of the jury in this scenario, he posits that condition (in 29c7-8) as follows: $\dot{\varepsilon} \varphi^{\prime} \tilde{\omega} \tau \varepsilon$

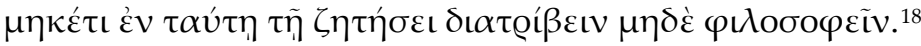

Once again, we have two verbal phrases - as made apparent in zétései diatribein and then in philosophein-connected by the presence of the two negatory markers: méketi and méde. The formulation makes for the rhetorical ambiguity (similar to what we have seen earlier in the use of kai). To understand this better, we can first consider a similar problem in English, which is the ambiguity inherent in using the either-or construct. Consider a

${ }^{18}$ The line in 29c7-8 is rendered by the various translators as follows: Ferriols: "Huwag ka nang mag-aksaya ng panahon sa iyong pananaliksik; huwag ka nang mamilosopiya;" Allen: "... that you no longer pass time in that inquiry of yours, or pursue philosophy;" Fowler: "... that you no longer spend your time in this investigation or in philosophy;" Grube: "... that you spend no more time on this investigation and do not practice philosophy;" Rowe: "... that you stop spending your time on this search of yours, and you stop doing philosophy;" Tredennick and Tarrant: "... that you give up spending time on your quest and stop philosophizing;" West: "... that you no longer spend time in this investigation or philosophize."

(c) 2019 Jesus Deogracias Z. Principe https://www.kritike.org/journal/issue 24/principe june2019.pdf 


\section{THE TASK OF PHILOSOPHIZING}

statement taking the form: do neither $\mathrm{x}$ nor $\mathrm{y}$; here, $\mathrm{x}$ and $\mathrm{y}$ may be distinct terms (she neither eats nor sleeps), or one is implicated in the other (she neither exercises nor tries to stay fit), or it might even be possible for them to be identical, with the repetition being for the sake of emphasis (she neither desires nor longs for me). So, similarly, the way we understand the link between zétései diatribein with philosophein is an open question.

In Grube, Rowe, and Tredennick and Tarrant, we find the use of "and" as the conjunction of choice, which, as stated earlier, serves to retain ambiguity; and as with the earlier line, ambiguity would allow a reader to see the terms of the two verbal phrases as distinct, which would, once again, allow for the further question of what "philosophy" should mean if distinguished from zétései diatribein. In Allen, Fowler, and West, we find the use of the connector, "or," which, again returning to a point made previously, still retains some ambiguity, but also lends itself more to a reading wherein one of the terms serves to clarify the other. The rendering of Ferriols is unique in that instead of using any word as a form of conjunction, he splits the sentence in two with a semi-colon: "Huwag ka nang mag-aksaya ng panahon sa iyong pananaliksik; huwag ka nang mamilosopiya."

The effect of this in one's reading of the text is decisive. The latter verbal phrase becomes a clear reiteration of what has gone previously. To spend time (diatribein) on this search (zétései) is what philosophizing (philosophein) is all about. There is, thus, no need to wonder further as to what else philosophizing might be apart from or distinct from this search. In Ferriols's rendering, pamimilosopiya is all about this pananaliksik. What would thus matter as we proceed is trying to arrive at a better understanding of what saliksik is all about.

Given that hypothetical offer of leniency presented by Socrates to himself, he then immediately responds with an obstinate refusal to abandon the task given to him by the god. As the line states in 29d4-6: ov $\mu \eta \dot{\eta} \pi \alpha u ́ \sigma \omega \mu \alpha \mathrm{L}$

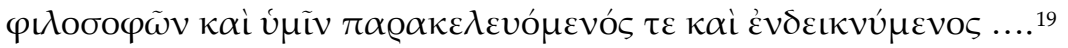

At first glance, it might seem as if our work here will become even more complicated by the presence not just of two verbs as we have seen so far, but this time, of three verbs-

\footnotetext{
${ }^{19}$ The line in 29c7-8 is rendered by the various translators as follows: Ferriols: “Walang tigil akong mamimilosopiya, magbibigay ng payo sa inyo; matatagpuan ninyo ako sa aking dating anyo." Allen: "I shall not cease to pursue wisdom or to exhort you, charging any of you ...;" Fowler: "I shall never give up philosophy or stop atop exhorting you and pointing out the truth to any of you ...; Grube: "I shall not cease to practice philosophy, to exhort you and in my usual way to point out to any of you ...;" Rowe: "I shall never stop doing philosophy, exhorting you all the while and declaring myself to whichever of you I meet ...;" Tredennick and Tarrant: "I shall never stop practicing philosophy and exhorting you and indicating the truth for everyone that I meet ...;" West: "I will certainly not stop philosophizing and I will exhort you and explain this ...."
}

(c) 2019 Jesus Deogracias Z. Principe

https://www.kritike.org/journal/issue 24/principe june2019.pdf

ISSN 1908-7330

(cc) BY-NC-ND 
$\dot{\varepsilon} \nu \delta \varepsilon \iota \kappa v v ́ \mu \varepsilon v o \varsigma$ - once again connected by the conjunction kai, with all the equivocities that such a construct permits, as we had seen earlier. However, this will not be the case when we look at the rendering of Ferriols: "Walang tigil akong mamimilosopiya, magbibigay ng payo sa inyo; matatagpuan ninyo ako sa aking dating anyo." The text has been streamlined to only bring in two verbs-mamimilosopiya and magbibigay ng payo-with the third verb of what Socrates does passively implied in the statement that follows "matatagpuan ninyo ako sa dati kong anyo."

This rendering of Ferriols deserves some comment. First, we can see how the second verb, parakeleuomenos has been translated into English by our translators using some form of "to exhort." There is, arguably, something gentler and less of an imposition on the other in the attitude present in Ferriols's translation of "magbibigay ng payo." This echoes the earlier difference in attitude between aggressive refutation, and milder questioning and scrutinizing of another. Second, the disappearance of the third verb in Ferriols may be justified as the succeeding sentence will clarify what is taking place. We shall later consider what takes place there, and also how it might help clarify one or both of the two earlier verbs. Third, with that third verb gone, in looking at the Ferriols translation, we need to consider only the relation of the two verbs present: mamimilosopiya and magbibigay ng payo.

In thinking of this line, we can first see in Tredennick and Tarrant, and also in West, the use of the conjunction, "and," again keeping open the question of what philosophy might mean when distinguished from the latter terms; Allen, and Fowler use "or," which may or may not echo the ambiguities of "and" in ways similar to what had already been discussed; finally, Grube, Rowe, and Ferriols make use of a comma. Again, the terms so construed may be interpreted with some ambivalence, but to reiterate the argument presented earlier, this form lends itself more to the interpretation that philosophy can be identified with-or at very least, involvesexhortation (or using Ferriols's rendering, whatever it is about which he shall be giving advice).

The content of this advice (or the specific exhortation, if one prefers the English renderings) is an open question, and we will discuss this at length in the third section of this essay. For now, let us summarize where we are at this point: Socrates speaks of an assessment of truth-claims in which he has been-and apparently still is-involved; he then speaks of philosophy, and yet he does so within constructs that make it an interpretative question as to how philosophy should be thought of in relation to some form of examination or exetazonta. Because forms of exetazonta were used to refer to the assessment of truth-claims, there is basis for supposing that philosophy is primarily all 


\section{THE TASK OF PHILOSOPHIZING}

about this refutation of others. ${ }^{20}$ But should one prefer it, there is also reason for considering whether philosophy involves more than that, perhaps involving a form of examination that remains distinct from the assessment of truth-claims and the refutation of other people. This seems to have been given form and expression by Ferriols in his choice of two verbs whose uses can be distinguished: usisa, for the assessing of truth-claim, and saliksik, for something more. But even before we could explore what this second term could mean, a complication has arisen: apparently, philosophy involves some kind of exhortation or advice-giving also. Let us examine what this could be about; we might find that this will help clarify what kind of inquiry or search or saliksik is involved in philosophy.

\section{Part 3: Caring as Effort}

The last line that we paid attention to shows the philosophical act as involving some form of exhortation which is how all the English translations render parakeleuomenos. We have seen that Ferriols translates this as "pagbibigay ng payo." A comment on the difference in attitude between the English and the Filipino verb has already been stated. Setting that aside for now, we can consider the question: what would the exhortation or the payo be about? As we shall see, Socrates seems to want his interlocutors to care.

This is how English translators almost always render the various forms of $\dot{\varepsilon} \pi \mu \varepsilon \lambda \varepsilon \varepsilon \tilde{\imath} \alpha$ that appear in the text. This is the first word that we find in the standard Greek-English lexicon, Liddell and Scott: the listing for epimeleia gives us care, attention, diligence. So, let us be clear: we are not calling into question the use of the word "care" to refer to epimeleia; still the question can be asked, what do we mean by care?

We might speak of a certain mother as caring for her children, and by that we would mean how she attends daily to all their needs. This woman's brother, the children's uncle, might also be said to care for them, although that might mean he has some fondness for them such that he gives them gifts on Christmas, the one time in the year he sees them. Or maybe ,I could tell you that my friend, Anna cares for the environment, and elaborate on all her work in certain environmental advocacies; but I could also remark that she cares for pizza, by which I simply mean that that is what she loves to eat.

The point here is that the word care could equally refer to something like an internal disposition or affect, on one hand, and maybe something directed externally into action, on the other, with all sorts of possible variations in between. Without having to elaborate on the various

${ }^{20}$ As seems to be Rowe's reading. See C. Rowe, translator's footnote in Plato, The Last Days of Socrates, note 49, p. 180.

(c) 2019 Jesus Deogracias Z. Principe

https://www.kritike.org/journal/issue 24/principe june2019.pdf

ISSN 1908-7330

(c) $)$ BY-NC-ND 
possibilities for the word itself, further, we can recognize how care allows for ambiguity in interpretation. This ambiguity, however, is remarkably absent in Ferriols. In his rendering, epimeleia becomes explicitly, and almost unequivocally, a matter of effort, and even struggle. This is made evident in the number of instances that he uses the words sikap and tiyaga. Let us look at this more closely.

Socrates reports that in his conversation with others, he chastises them, his fellow Athenians, asking them whether or not it shamed them that they would excessively غ̇ $\pi \mu \varepsilon \lambda$ oú $\mu \varepsilon v o \varsigma$ or, "care" for money (29d9). In Ferriols, this is rendered as "... hindi mo ikinahihiyang magtiyaga upang humigit sa lahat any iyong kayamanan." And Socrates adds in 29e2-3 that it is further shameful for them to be so preoccupied while "not caring"

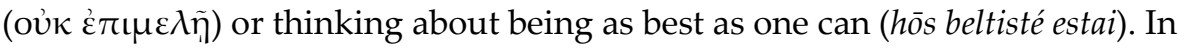
Ferriols, this is rendered as "hindi ka ba nagsisikap, hindi ba mahalaga sa iyo na ikaw ay maging pinakamagaling?"

Socrates then adds that if ever one of his interlocutors should claim that he does $\dot{\pi} \pi \mu \varepsilon \lambda \varepsilon \tilde{\imath} \sigma \theta \alpha \iota$ or, "care," then he, Socrates, would not simply let the other off, but that Socrates will continue talking with him and testing him (in 29e3-a5). In Ferriols, Socrates describes such a man as "isa sa inyo na nagsasabing nagsisikap siya."

This active aspect of the exhortation is made even more pronounced and also object-specific when he urges that a person should not $\dot{\varepsilon} \pi \iota \varepsilon \lambda \varepsilon \tilde{\varepsilon} \sigma \theta \alpha \mathrm{t}$ or, "care" for his body or for money as much as-or more than-he would his own self (tés psuchés), and on this regard rather than any other, try to be at one's best (aristé estai) in 30a8-b2. In Ferriols, this is rendered as “... huwag pag-aabalahan ang katawan, huwag gawing unang layon ang kuwarta; walang dapat makadaig sa maningas na pagtiyatiyaga alang sa tunay na sarili, nang ito'y maging tunay na magaling." The insertion of "maningas na pagtiyatiyaga" in the line actually does not directly translate any particular Greek term, but stands for the implied epimeleia in the line, and in the reading of Ferriols, what is emphasized is that one should assiduously strive for what one truly cares about. We might note two distinct verbs in the Filipino translation of this line: pag-aabala and pagtiyatiyaga. We shall return to this shortly.

Socrates speaks of his own task, in 31b5, as going around like a father or elder brother persuading others to $\dot{\pi} \pi \mu \varepsilon \lambda \varepsilon \tilde{\tau} \sigma \theta \alpha \mathrm{l}$, "to care" for virtue (aretés). Ferriols translates this as "nagbibigay loob na pagtiyagaan ninyo ang tunay na kabutihan."

Further down in 36c5-d2, he reiterates the exhortation, repeating the verb often, that he urges each one to $\mu \eta \delta \varepsilon v o ̀ \varsigma ~ \varepsilon ं \pi \mu \mu \varepsilon \lambda \varepsilon \tilde{\imath} \sigma \theta \alpha \iota$ or "not care" about what one might possess, but instead to $\dot{\varepsilon} \pi \mu \varepsilon \lambda \eta \theta \varepsilon i ́ \eta$ or "care" about one being at one's best (beltistos) and wisest (phronimōtatos). Ferriols renders 


\section{THE TASK OF PHILOSOPHIZING}

this as "huwag muna niyang pag-abalahan ang pag-aari kundi ang sarili: pagsikapan nyang humantong sa ubod ng kabutihan at katinuhan." Again, we find the emphasis on effort, as well as the pair of verbs, abala and sikap, echoing the earlier pair of abala and tiyaga.

We will find one more instance of that pairing of distinct verbs, this time, towards the end of the Apologia, in 41c4-7. Here, we see Socrates imploring his listeners to act towards his own sons in the same way that he had acted towards them: to observe if they happen to $\dot{\pi} \iota \mu \varepsilon \lambda \varepsilon \tilde{\varepsilon} \sigma \theta \alpha \mathrm{l}$, or, "be caring," for money or any other thing rather than virtue, and to reproach

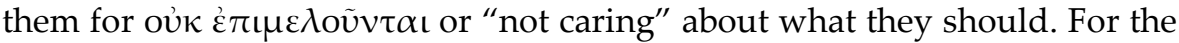
earlier form of the verb, Ferriols uses "pinag-aabalahan," whereas in the second, he gives us "sapagkat hindi nila pinagtiyatiyagaan ang nararapat."

The juxtaposition of paired verbs in the three instances mentioned above is telling. In 30a8-b2, it was abala for the body, and tiyaga for the concern for the true self. In 36c5-d2, it was again abala for possessions, and sikap for being the best and wisest one can be; this is echoed once more in 41c4-7, with abala again for money and other trivialities, and tiyaga for that which rightly deserves effort, and this, we can deduce, is virtue. This choice of terms could be taken as indicative of Ferriols's sense of what philosophizing requires: it is easy enough for one to have a care or concern or simply be preoccupied (abala) with something, which is honestly unimportant, but that which truly matters will require effort and hard work (sikap and tiyaga) if one is to truly care for it. This idea would have to be inferred in the English translations which are unwilling (or perhaps unable?) to make this an explicit point of the text.

We will find, still further, traces of this attitude in the rendering of Ferriols even where it is not a matter of translating some form of epimeleia.

For instance, let us return to the hypothetical scenario posited by Socrates wherein he is conversing with one who claims to care; should he find that this person is only pretending, he will then "rebuke him for making things that are most valuable his lowest priority and giving higher priority to things of lesser worth." This is how Rowe translates the line in 29e5-30a2:

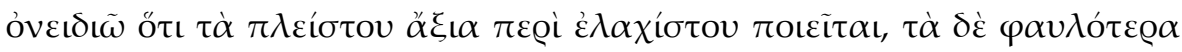
$\pi \varepsilon$ Qi $\pi \lambda$ cíovos, closely following how one makes (poieitai) much worth (ta pleistou axia) about what actually is worth little (peri elachistou), and conversely makes little (ta phaulotera) about what actually is worth more (peri pleionos). Let me reiterate how, in the English, the ambiguity is generally present as to the extent to which one should see the disposition in terms of internal affect or in terms of active effort. By contrast, in Ferriols, we find: "pangangaralan ko siya na ang tiyaga na dapat ibuhos sa mahalaga ay kanyang inaaksaya sa kabuktutan, at katamaran ang kanyang inihaharap sa mahalaga." It becomes clear in the comparison that the notion of an efforttiyaga-that one ought to exercise, as opposed to laziness-katamaran-or

(c) 2019 Jesus Deogracias Z. Principe

https://www.kritike.org/journal/issue 24/principe june2019.pdf

ISSN 1908-7330

(c) $)$ BY-NC-ND 
lack of effort that one ought to dispel, might not be something explicitly expressed in the original text, but is a unique and meaningful inference incorporated in the Ferriols translation.

A further trace of this emphasis on effort is found in 36c4-d2; we had already seen this text earlier, paying attention to how Socrates exhorts us to not care for anything other than being best in terms of being wisest. But now let us turn to what Socrates says about what he, himself, is doing; in speaking of his own task, Socrates uses the verb: epicheirōn. Translated by Allen as "undertook," and by West as "attempted," all the other English translations use some form of the common English verb, "try," for this. One would therefore understand if Ferriols had used here the term, "subok," providing the simplest Filipino word for "try," but instead we find him using again, "tiyaga," when he says, "Pinagtiyagaan kong hikayatin ang bawat isa ...." There is strong emphasis in the Ferriols translation of the continued effort on the part of Socrates' own act of exhorting, which is reflected in the effort that he is demanding from his interlocutors.

As one last indicator of this emphasis on effort in the Ferriols translation, we can return to the way Socrates affirms that he will not give up on the task. We had seen earlier his response to the imagined offer of leniency if he would just desist from what he has been doing. His emphatic reply, in $29 \mathrm{~d} 4$, is to say that he will continue philosophizing. The translations of ov $\mu \eta \dot{\eta}$

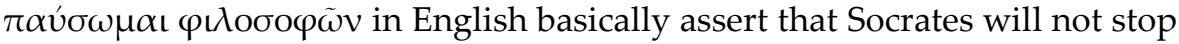
in philosophizing even with the offer of leniency. ${ }^{21}$ Again, to mimic this, Ferriols could have simply chosen to translate this in Filipino as "hindi ako titigil sa pilosopiya," but what we see, instead, in the Ferriols rendering is "walang tigil akong mamimilosopiya." This term in Filipino not only covers that decision to not stop when offered leniency, but it also expresses a constancy, a continued and tireless effort that could be inferred, but is not quite explicit, in the English renderings.

To conclude this section, we can note how Socrates gives some indicators of what he believes people should rightly care for, and this may be understood in terms of care for the self. This is thought of as a priority towards being at one's best in terms of wisdom and virtue, rather than being preoccupied with possessions. However, a significant point about all this which is much more explicit in the Ferriols rendering than any of the English ones is the disposition that philosophy requires, that it is not about having a care in some blasé manner or passionate internal affect, but requires a willingness to commit to sustained effort and striving.

${ }^{21}$ See note 19 above.

(c) 2019 Jesus Deogracias Z. Principe https://www.kritike.org/journal/issue 24/principe june2019.pdf

ISSN 1908-7330 


\section{THE TASK OF PHILOSOPHIZING}

\section{Conclusion: Striving to Know the Good}

We started with the question: how can we understand what philosophy is as has been given to us in a specific philosophical text, the Apologia? The question is compounded by a consideration of what a particular translation of the text gives us, such that we can rephrase the previous question in terms of: what does Ferriols's Socrates tell us about what it means to philosophize as can be found in his Apolohiya?

We dismissed the idea that we can simplistically claim that Socratic philosophy is all about "the elenchus," as it might be tempting to immediately suppose; with that cleared out of the way, we looked more closely at what the text actually offers.

We explored how Socrates recounts this double examination of assessing the oracle's pronouncement of his supposed wisdom by assessing what other people say; in his doing so, he has garnered many enemies, as his work seems to involve his constant refutation of others. There might be reason to suppose that this, in itself, is what constitutes the philosophical act. When one sees a verb used to refer to this cross-examination (exetazonta), and then, later, sees that verb again being mentioned alongside the use of the word "philosophy," one could take this love of wisdom to be one and the same with the assessment of truth-claims. One might say that the mission consists of nothing more than cross-examination and a demonstration to others of their ignorance. ${ }^{22}$ And yet one might see it otherwise and recognize that there could be more to what Socrates does than simply refuting other people's statements. ${ }^{23}$

While a haphazard use of terms could point us in either interpretive direction, we see Ferriols markedly delineating between two activities-usisa and saliksik - while his further word choices present an attitude and character to Socrates that is less aggressive and more genial than in some of the other translators. A significant point to raise here is that the assessment of others' truth-claims should not be isolated from the exhortative aspect of what Socrates has been doing, as he details to us how he has always been urging the people he converses with to care more greatly for some things rather than others. We have tried to see how the rendering of Ferriols of epimeleia with the Filipino words sikap and tiyaga gives us-over and above the somewhat weak care often used in the English translations - that sense of constant effort or active pursuit or striving for what truly matters.

${ }^{22}$ G. Rudebusch, Socrates (West Sussex: Wiley-Blackwell, 2009), 32.

23 "But Socrates does not just seek to call into question his interlocutors' false beliefs about how one ought to live; he also hopes to make substantive and constructive progress towards developing a correct understanding of how one ought to live." T. C. Brickhouse and N. D. Smith, Plato's Socrates (New York: Oxford University Press, 1994), 12.

(c) 2019 Jesus Deogracias Z. Principe

https://www.kritike.org/journal/issue 24/principe june2019.pdf

ISSN 1908-7330

(c) $\mathrm{BY}-\mathrm{NC}-\mathrm{ND}$ 
More concretely, what is this striving all about? What is it that truly matters and about which I ought to show sikap and tiyaga? We are told it is about arête or virtue or kabutihan; and we are told, it is about phronimōtatos or being best concerning wisdom or katinuhan. This is all well and good; we know what it is about. Or do we? This is the all-important question; do we know how we ought to live, do we know virtue, or do we only think that we know (nagmamarunong)? Our ignorance is precisely ignorance on how one is to act with kabutihan and katinuhan. But if our ignorance echoes Socrates's own, this ignorance is not negative but positive; it is a challenge before us. Or as Ferriols himself puts it in his commentary, "Itong pag-angkin na hindi siya marunong ay hindi galing sa dilim ng walang isip, kundi galing sa liwanag ng pag-uunawa." 24 The realization of ignorance is that first trace of wisdom by which one understands that one needs to search further. This is why inquiry-saliksik-can and must still be done, with untiring effort and striving on our part.

What more can we say of saliksik? In an often quoted line from the Apologia, it is often stated that "the unexamined life is not worth living,"

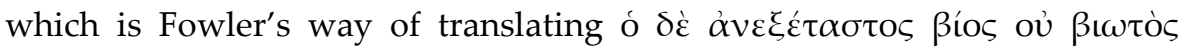
$\dot{\alpha} v \theta \varrho \omega \pi \omega$ in 38a5-6, and the other English translations more or less echo this rendering. Ferriols gives us "palibhasa'y ang buhay na hindi sinasaliksik ay hindi buhay tao." But since this is a statement that is expressed negatively, what is the positive corollary?

Often forgotten in the process of turning that quote into a cliché is the

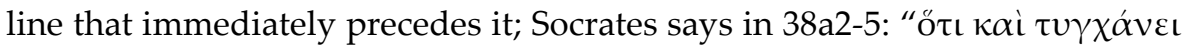

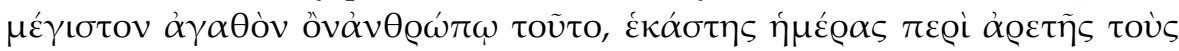

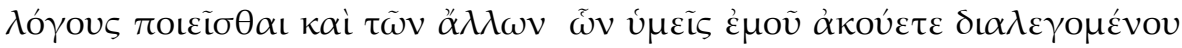

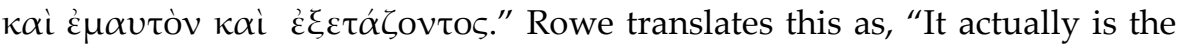
greatest good for a human being to get into discussion, every day, about goodness and the other subjects you hear me talking and examining myself and others about." Or as Ferriols puts it, "... na pinakadakilang biyaya sa tao na sa balang [sic] ${ }^{25}$ araw nakakasalita siya ukol sa tunay na kabutihan at ukol sa mga naririnig ninyong pinag-uusapan ko, habang sinasaliksik ko ang aking sarili at ang aking kapuwa ...." This allows us to better understand what this philosophical task involves: an inquiry about becoming best and wisest and virtuous that takes place on a daily basis. This inquiry or search is dialogical, not simply a matter of personal introspection or individual reflection, but is conducted through one's engaging with and speaking to others even as one looks into how we live our lives. 1999), 103.

${ }^{24}$ Roque Ferriols, Mga Sinaunang Griyego (Quezon City: Ateneo de Manila University,

${ }^{25}$ I presume Ferriols, here, means "bawat."

(c) 2019 Jesus Deogracias Z. Principe https://www.kritike.org/journal/issue 24/principe june2019.pdf ISSN 1908-7330 


\section{THE TASK OF PHILOSOPHIZING}

Now, when we posit that the main point is inquiry, there might be reason for one to suppose that the conversation is instrumental in character; by talking to others, I get to clarify for myself my own thinking about what is good. Another, more generous perspective is to see not only the conversation but the inquiry itself as shared. As one commentator posits, perhaps the goal here is knowledge of the most important things, but this can only be attained through a shared search, involving a readiness to learn from others, and so, philosophy is an invitation to others who may be just as ignorant to join in the search. ${ }^{26}$ This seems to echo Ferriols's own position, when he remarks, "Natauhan [si Sokrates] na itinalaga sa kanya ng diyos ang isang gawain: Tulungan ang kanyang kapuwa tao na magpakatao." 27 This might be a reason for the general gentleness of Socrates in the translation of Ferriols, as we have noted earlier; while the English translations have Socrates more aggressively refuting and exhorting, in Ferriols, we find him more genially and collegially engaged in questioning and offering advice. The people one engages in dialogue are not competitors, but companions.

There is a shared inquiry, through conversation, on what it means to be virtuous, to be wise, to be truly human. One might even add that, in potential response to an often-stated criticism against philosophy that it is all about conversation, that it is just all "talk," in this text Ferriols, presents to the reader an image of the inquiry as active, not only in the sense that one is actively inquiring, but also that the inquiry is of what one should actively be doing. As Ferriols puts it, "Sa bawat kalagayan ng buhay, tinatanong [ni Sokrates]: Ano ang gagawin dito ng isang mabuting tao? Ano ang panawagan ng katarungan ngayon? Tinatanong niya ito habang pinagsisikapan niyang gawin ang gagawin ng mabuting tao, isagawa ang katarungan." 28 This perhaps allows us to understand better why epimeleia is consistently translated in terms of sikap and tiyaga; this is both an inquiry towards and a pursuit of living ethically, of heeding the call of justice, and both these aspects call for much effort.

Philosophy, then, requires-but should not be identified with - the assessment of truth-claims (usisa); certainly, it does not relish the deconstruction of another's position for its own sake. This starting point serves the need to free the self from the illusion of knowing and to accept ignorance as the condition for sincere searching (saliksik). The object of search is basically ethical, living the best life possible, and this requires having care

\footnotetext{
${ }^{26}$ H. Benson, "Socratic Method," in The Cambridge Companion to Socrates, ed. by D. R. Morrison (Cambridge: Cambridge University Press, 2011), 181-183.

${ }^{27}$ Roque Ferriols, Mga Sinaunang Griyego (Quezon City: Ateneo de Manila University, 1999), 104.

${ }^{28}$ Ferriols, Mga Sinaunang Griyego, 105.

(c) 2019 Jesus Deogracias Z. Principe

https://www.kritike.org/journal/issue 24/principe june2019.pdf

ISSN 1908-7330
}

(cc) BY-NC-ND 
(epimeleia) for what truly matters, and the pursuit and practice of this calls for our striving and our perseverance (tiyaga).

Ferriols says of Sokrates that "gumagawa siya ng kapaligiran upang maging posible sa taong ito na siya'y makakita ... upang magpakatao siya sa wakas." 29 We might extend this statement to Ferriols himself, and say that in true Socratic spirit, he has provided us through his Apolohiya with a window looking into a world of earnest and unjaded philosophical inquiry. Through his nuanced use of Filipino, we are presented with a unique and eloquent expression of the Socratic invitation to acknowledge our ignorance and to pursue an active life of inquiry and of striving to become more fully human.

Department of Philosophy, Ateneo de Manila University, Philippines

\section{References}

Benson, H., "Socratic Method," in The Cambridge Companion to Socrates, ed. by D. R. Morrison, (Cambridge: Cambridge University Press, 2011).

Brickhouse, T. C. and N. D. Smith, Plato's Socrates, (New York: Oxford University Press, 1994).

Clay, D., Platonic Questions: Dialogues with the Silent Philosopher, (University Park, Pennsylvania: The Pennsylvania State University Press, 2000).

De Strycker, E. and S. R. Slings, "Plato's Apology of Socrates," in Plato's Euthyphro, Apology, and Crito: Critical Essays, ed. by R. Kamtekar, (Lanham: Rowman and Littlefield, 2005).

Ferriols, Roque, Mga Sinaunang Griyego (Quezon City: Ateneo de Manila University, 1999).

Plato, "Apology," trans. by G. M. A. Grube in Plato: Complete Works, ed. by J. Cooper (Indianapolis: Hackett, 1997). "Apology," trans. by T. G. West, in Four Texts on Socrates, rev. ed., ed. by T. G. and G. S. West (Ithaca: Cornell University Press, 1998). Plato - Volume 1: Euthyphro, Apology, Crito, Phaedo, Phaedrus, trans. by H. N. Fowler, (Cambridge, Mass.: Harvard University Press, 1914).

The Dialogues of Plato: Volume 1, trans. by R. E. Allen, (New Haven: Yale University Press, 1984).

The Last Days of Socrates, trans. by H. Tredennick and H. Tarrant,

(London, Penguin, 1993).

The Last Days of Socrates, trans. by C. Rowe (London, Penguin, 2010).

${ }^{29}$ Ibid., 104.

(c) 2019 Jesus Deogracias Z. Principe https://www.kritike.org/journal/issue 24/principe june2019.pdf ISSN 1908-7330 


\section{THE TASK OF PHILOSOPHIZING}

Robinson, R., "Elenchus," in Socrates: Critical Assessments-Volume 3: Socratic Method, ed. by W. J. Prior, (London: Routledge, 1996).

Rudebusch, G., Socrates (West Sussex: Wiley-Blackwell, 2009).

Woodruff, P., "Expert Knowledge in the Apology and the Laches: What a General Needs to Know," in Socrates: Critical Assessments-Volume 1: The Socratic Problem and Socratic Ignorance, ed. by W. J. Prior, (London: Routledge, 1996). 